\section{Bibiliography}

Feitelberg, Samuel B. (1966). Basic considerations of a job description. Phys. Ther. 46, 383-386. 386.

Lister, Marilyn J. (1966). Performance evaluation of the new staff member. Phys. Ther. 46, 387-390. 387-390.
Rochelle, Donna (1966). How to answer questions. Phys. Ther. 46, 428.

Todd, J. W. (1977). The use of hospitals. 6 Analyses. Update, April, 935-938.

Kenly, Judith D. (1972). A supervisor's view of staff evaluation. S. Afr. J. Physiother. 28, 2-4.

Whitfield, A. G. (1978). Chair a committee. Br. Med. J. 2, 936-937.

\title{
PRELIMINARY THOUGHTS ON AUDITING THE EFFICIENCY OF A PHYSIOTHERAPY SERVICE USING A GOMPUTER PROGRAMME
}

\author{
M. J. RUNNalls, Dip. Physio., C.T.P. (Cape Town)*
}

\begin{abstract}
The initiation of a documentation audit of the efficiency of physiotherapy services provided in a large general teaching hospital is discussed. Results and trends of behaviour as analysed by computer programmes are shown.
\end{abstract}

\section{INTRODUCTION}

The Tygerberg Hospital is not only a large general teaching hospital but also part of a large provincial hospital (state controlled) organisation. Thus, because of its very size (1 750 beds) and the hierarchy in the managerial system there will naturally be certain intrinsic problems. To be confident that there is an adequate physiotherapy service in both out-patient department and wards is not easy. It is also well nigh impossible for the senior physiotherapy staff to keep track of all that occurs. The fact that a junior or even a senior member of staff, is unhappy, or perhaps inadequate as regards their work potential and capacity can go unnoticed. It is also difficult to defend the department against just or unjust criticism from higher authorities, the medical profession, nursing profession, other allied health services and peers unless its effectiveness (the case) can be substantiated very clearly. Furthermore, it should be remembered that litigation will inevitably become more prevalent and substantiative evidence again will be essential to defend the case.

\section{METHOD}

With these problems in mind a documentation audit has been instituted based on the work of Khan and Howroyd (1976) who posed the following questions:

1. Is an acceptable standard of care being provided?

2. Does the present standard of care show any improvement over previous years?

3. Is the staff competent?

4. Is full use of resources being made?

Auditing of documentation becomes a way of assessing the efficiency of the department. Fully realizing that this is purely a "documentation" audit it can, however, be regarded as a relevant and reasonable measurement of efficiency of the services provided. Such an audit can

* Senior Lecturer and Head of Department of Physiotherapy, University of Stellenbosch and Tygerberg Hospital.

Received 30 April 1980.

\section{OPSOMMING}

Die instelling van' $n$ dokumentasie-oudit van die doeltreffendheid van fisioterapie-dienste wat in 'n groot opleidingshospital voorsien word, word bespreek. Resultate en gedragspatrone soos deur rekenaar-programme ontleed, word aangedui.

be evolved around two focal points, and the Problem Oriented Medical Record approach propagated by Weed (1968, 1971). The two focal points are:

1. The physiotherapist viz. the measurement of professional competency and

2. the system viz. the identification of problems which limit the system and thus the competency of the physiotherapist.

With regard to the physiotherapist there are four characteristics of professional competency which can be analysed:

1. Completeness: Are all the data fully recorded? Are all the problems identified? Are there plans pertaining to all the problems?

2. Reliability: Are the data accurate? Are all the data kept up to date? Are all the plans instituted? Is there evidence that the latest treatment modalities are being implemented?

3. Sound analytical sense: Is there evidence that th data obtained are used to solve the problems? 1 . the plan that has been developed relevant to the data? Does the plan take cognisance of the latest treatment techniques? Are all the plans realistic?

4. Efficiency: Are the problems solved within a reasonable amount of time? Are alternative treatment methods implemented when necessary and as soon as possible?

A documentation audit that would fulfil all the abovementioned factors with certain measurable criteria had to be established. For this purpose audit forms for longterm patients (hospitalization of more than 14 days) and and short-term patients (hospitalization of less than 14 days) were evolved. These forms were drawn up so that the results could be computerized and were based on the form proposed by Khan and Howroyd (1976). (Figs. 1 and 2). A short computer programme was written to calculate the percentages for each sub-section of the audit form. These percentages were then used for furthere analyses. By means of the BMDP9D programme of the BMD programme package a monthly analysis of efficiency was possible. Further computer programmes were set up to show the trends of behaviour in the various sub-sections of the established criteria for efficiency as well as to establish auditor bias. 
Folder No. $\square \square \square \square \square \square \square \square$

Date of reference

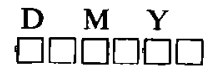

\section{TYGERBERG HOSPITAL DEPARTMENT OF PHYSIOTHERAPY AUDIT OF SHORT-TERM TREATMENT}

$\mathrm{N} / \mathrm{A}=8$ or 88

1. Referral

*1.1 Authorized referral

1.2 Patient seen within 24 hours

*1.3 Referral has primary diagnosis/requires evaluation to help diagnose

1.4 Condition for which treatment is required is specified

1.5 Referral has sufficient relevant information

*1.6 Contra-indication (if any) mentioned

\begin{tabular}{cccr} 
Yes & Perhaps & No & Points \\
6 & 3 & 0 & $\square$ \\
6 & 1 & 0 & $\square$ \\
6 & 3 & 0 & $\square$ \\
2 & 1 & 0 & $\square$ \\
2 & 1 & 0 & $\square$ \\
6 & 3 & 0 & $\square$ \\
\hline
\end{tabular}

2. Assessment

2.1 History

2.2 Objective findings

2.3 Subjective findings

2.4 Home/work situation noted

2.5 X-ray and laboratory findings noted

\begin{tabular}{rrrr}
2 & 1 & 0 & $\square$ \\
10 & 5 & 0 & $\square$ \\
4 & 2 & 0 & $\square \square$ \\
2 & 1 & 0 & $\square$ \\
2 & 1 & 0 & $\square$ \\
\hline
\end{tabular}

3. Treatment

3.1 Treatment plan outlined

3.2 Report to/or discussion with the referring doctor

*3.3 Safety measures in administration of treatment noted

3.4 Treatment noted on each visit

3.5 Frequency of treatment sufficient

$\begin{array}{llll}2 & 1 & 0 & \square \\ 6 & 3 & 0 & \square \\ 6 & 3 & 0 & \square \\ 2 & 1 & 0 & \square \\ 2 & 1 & 0 & \square\end{array}$

4. Progression

*4.1 Improvement noted at least once a week

4.2 Treatment plan changed to suit patient's current condition and reasons given

$\begin{array}{lll}6 & 3 & 0\end{array}$

$\begin{array}{lll}6 & 3 & 0\end{array}$

\section{Discharge and follow-up procedures \\ 5.1 Present condition noted \\ 5.2 Total discharge or future treatment noted \\ 5.3 Homecare and follow-up noted where necessary \\ 6. General \\ 6.1 All entries dated and signed \\ 6.2 Appropriate utilization of professional time \\ 6.3 General neatness}

Department Audited

$2 \quad 1$

0

\begin{tabular}{rrr}
\hline Audited by & Team No. & $\square \quad \square$ \\
$\square \square$ & Date of Audit & $\square \square \square \square \square \square$ \\
\hline $\mid$ S 141110111
\end{tabular}

Fig. 1

An auditing committee of five representatives of the most senior to the most junior members of staff were appointed on a three monthly basis. In this way it was hoped that any auditor bias could be countered. The auditors and the various departmental areas were assigned numerical values. Each auditor was responsible for certain departmental areas and drew a treatment torm for auditing per week from each department. For departments where more than one physiotherapist was working a form per week per physiotherapist was drawn. were forwarded for analysis.

\section{DISCUSSION}

The Institution of this system initially met with some resistance by the physiotherapists who regarded it as a nuisance to be $100 \%$ accurate both with documentation of the treatment and when auditing the treatment forms. The latter forms are rejected by the computer centre if they are not completed accurately! The implications and function of the documentation are now understood and valued by the physiotherapists. The aims of documentation are thus:

1. to assess the standard of care being provided 
TYGERBERG HOSPITAL

DEPARTMENT OF PHYSIOTHERAPY

AUDIT OF LONG-TERM TREATMENT

Folder No.

Date of reference

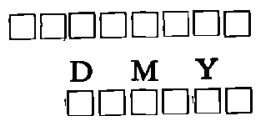

$\mathrm{N} / \mathrm{A}=8$ or 88

1. Referral

*1.1 Authorized referral

1.2 Patient seen within 24 hours

*1.3 Referral has primary diagnosis/requires evaluation to help diagnose

1.4 Condition for which treatment is required is specified

1.5 Referral has sufficient relevant information

*1.6 Contra-indication (if any) mentioned

\begin{tabular}{cccr} 
Yes & Perhaps & No & Points \\
6 & 3 & 0 & $\square$ \\
2 & 1 & 0 & $\square$ \\
6 & 3 & 0 & $\square$ \\
2 & 1 & 0 & $\square$ \\
2 & 1 & 0 & $\square$ \\
6 & 3 & 0 & $\square$ \\
\hline
\end{tabular}

2. Assessment

2.1 History

*2.2 Objective findings

*2.3 Subjective findings

2.4 Home/work situation noted

$2.5 \mathrm{X}$-ray and laboratory findings noted

2.6 Summary of problems

2.7 Patient seen as a whole

\begin{tabular}{rrrr}
2 & 1 & 0 & $\square$ \\
10 & 5 & 0 & $\square \square$ \\
4 & 2 & 0 & $\square$ \\
2 & 1 & 0 & $\square$ \\
2 & 1 & 0 & $\square$ \\
2 & 1 & 0 & $\square$ \\
2 & 1 & 0 & $\square$ \\
\hline
\end{tabular}

3. Treatment

3.1 Treatment plan outlined

3.2 Treatment plan evident of stated problem/s

3.3 Report to or discussion with the referring doctor

3.4 Additional treatment noted

*3.5 Safety measures in administration of treatment noted

3.6 Treatment noted on each visit

3.7 Frequency of treatment sufficient

\begin{tabular}{llll}
2 & 1 & 0 & $\square$ \\
6 & 3 & 0 & $\square$ \\
6 & 3 & 0 & $\square$ \\
2 & 1 & 0 & $\square$ \\
6 & 3 & 0 & $\square$ \\
2 & 1 & 0 & $\square$ \\
2 & 1 & 0 & $\square$ \\
\hline
\end{tabular}

4. Progression

*4.1 Improvement noted once per month

*4.2 Treatment plan changed to suit patient's condition/changed within a week if not effective

4.3 Changes and reasons for noted

$\begin{array}{lll}6 & 3 & 0\end{array}$

\begin{tabular}{lll}
6 & 3 & 0 \\
2 & 1 & 0 \\
\hline
\end{tabular}

5. Discharge and Follow-up Procedures

5.1 Present condition noted

5.2 Total discharge or future treatment noted

5.3 Homecare and follow-up noted where necessary

\section{General}

6.1 All entries dated and signed

6.2 Appropriate utilization of professional time

6.3 General neatness

$\begin{array}{lll}2 & 1 & 0 \\ 2 & 1 & 0\end{array}$

$2 \quad 1 \quad 0$

$\square$

Department Audited

$\begin{array}{llll}2 & 1 & 0 & \square \\ 2 & 1 & 0 & \square \\ 2 & 1 & 0 & \square \\ & \text { Code } & \text { Sub } & \square \square\end{array}$

Audited by

Team No.

Date of Audit

D $M \quad Y$

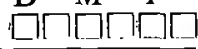

$\overline{S 141110111}$

Fig. 2

2. to assess improvement in the standard of care provided

3. to assess the competency of the staff

4. to identify any problems within the system which prevent treatment being effected competently

5. to provide continuity of patient care between physiotherapists
6. to provide continuity and, co-operation between members of the health team

7. to provide clinical records for research purposes

8. to provide evidence in the case of possible litigation.

The immediate effect of instituting the auditing programme was the pin-pointing of problems in several 
TYGERBERG HOSPITAL/HOSPITAAL

DEPARTEMENT FISIOTERAPIE : DEPARTMENT OF PHYSIOTHERAPY FISIOTERAPIE-BEHANDELING/TREATMENT BY PHYSIOTHERAPY

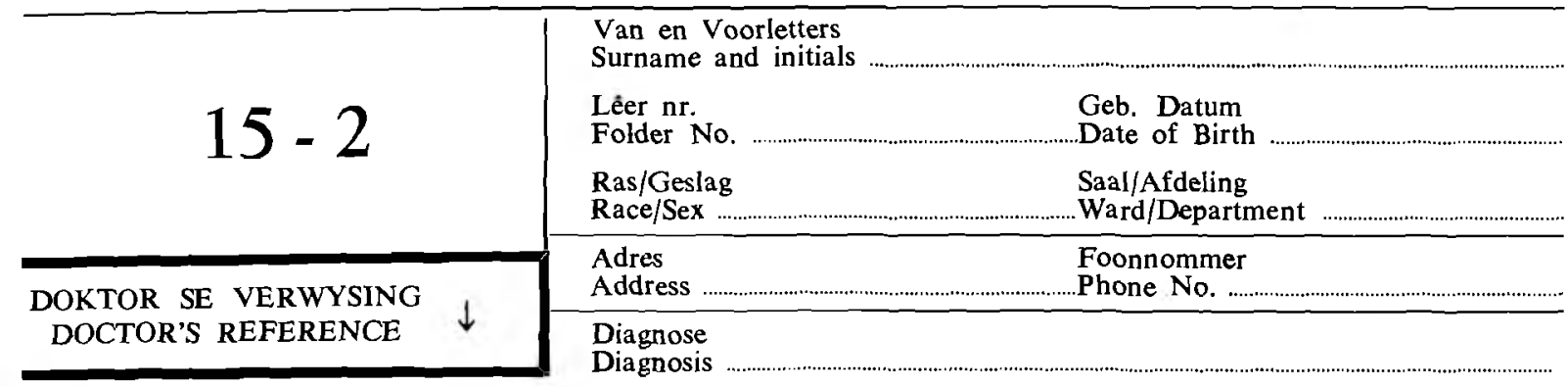

Behandeling voorgestel

Treatment suggested

Teen-indikasie en ander opmerkings

Contra-indication and other remarks

Geneesheer

Doctor
Datum

Date
Datum van Opvolgkliniek

Date of next Clinic

FISIOTERAPIE-BEHANDELING / TREATMENT BY

PHYSIOTHERAPY

Fisioterapeut-in-bevel

Physiotherapist-in-charge

Vir voltooing deur Fisioterapeut by Ontslag:

For completion by Physiotherapist on Discharge:

Rehabilitasie voltooid Ja/Nee

Rehabilitation completed Yes/No

\section{Verwys na:}

Referred to:

1. Geneesheer, Naam

Doctor, Name

2. Fisioterapie Buitepasiënt Departement

Physiotherapy Out-patient Department

3. Maatskaplike Werker, Naam

Social Worker, Name

Arbeidsterapeut, Naam

Occupational Therapist, Name

5. 5. Daghospitaalorganisasie, Naam

Day Hospital Organisation, Name

6. Rehabilitasie-kJiniek (TBH)

Rehabilitation Clinic (TBH)

7. Ander

Other

Handtekening van Fisioterapeut:

Signature of Physiotherapist:

\section{Datum van Ontslag:}

Date of Discharge:

Tuisoefeningprogrạm Ja/Nee Home Exercise Programme Yes/No
Geskik vir werk Ja/Nee

Fit for work Yes/No
Datum van verwysing

Date of referral

Datum van eerste afspraak

- Date of first appointment

Datum van verwysing

Date of referral

Datum van verwysing

Date of referral

Datum van verwysing

Date of referral

Datum van verwysing

Date of referral

Fig. 3

areas where there were no fixed data bases for clinical assessments. This resulted in the formulation of several new specific evaluation forms, e.g. for amputation and intensive care patients. Furthermore, the audit demanded a global summary of each patient. This resulted in the formation of a new departmental reference form (Fig. 3) which was to precede each specific evaluation. This form embraces at a glance a précis of the patient's particulars, the medical referral and the total rehabilitation programme, and indicates the physiotherapists responsible for the treatment programme.
From the table, Fig. 4, it can be seen that initially the efficiency of treatment of the short-term patients lagged somewhat behind that of the long-term patients. Because this system was in its initial stages it was decided to place the average totals for the short-term and longterm patients in large figures on the staff tearoom notice board each month. Little was discussed but weaknesses were pointed out individually to the physiotherapists. It is possible to draw the audit form and point out specific problems and discuss them. As can be seen there was an overall improvement in the percentage efficiency from 
Analysis of some pertinent results from April-December 1979

1. Total percentage efficiency

$\begin{array}{lccc}\text { Month } & \text { Long and short-term } & \text { Long-term } & \text { Short-term } \\ \text { April } & 76,1 & 80,1 & 70,0 \\ \text { May } & 70,3 & 76,2 & 65,9 \\ \text { June } & 64,7 & 74,3 & 58,6 \\ \text { July } & 75,7 & 82,5 & 71,6 \\ \text { August } & 80,9 & 84,5 & 78,3 \\ \text { September } & 76,4 & 80,8 & 72,8 \\ \text { October } & 76,4 & 80,3 & 73,8 \\ \text { November } & 81,4 & 81,5 & 81,4 \\ \text { December } & 82,7 & 85,1 & 81,4\end{array}$

Fig. 4

April-December, 1979.

Further analysis of the short-term audits showed that the weakest areas were the sub-sections for evaluation and treatment. This was not particularly gratifying but an in-depth analysis reveals that the areas which needed more attention were:

2.4 Home/work situation noted

$2.5 \mathrm{X}$-ray and laboratory findings noted

3.1 Treatment plan outlined

3.2 Report or discussion with the doctor who referred the patient

3.3 Safety measures in the administration of treatment noted.

A general trend of improvement in these sections was noted over the nine months of the audit. (See Fig. 5)

System changes envisaged:

1. Many weak points have been identified and improved. Some sections have, however, still not improved is much as hoped. Because other factors have remained it constantly high values and show little change it would seem worth weighting the areas requiring more improvement more heavily. Before taking this step, however, the present system will be continued for
SHORT-TERM RESULTS

$\begin{array}{lcc} & \text { Evaluation } & \text { Treatment } \\ \text { April } & 69,5 & 55,5 \\ \text { May } & 56,2 & 38,4 \\ \text { June } & 49,8 & 32,9 \\ \text { July } & 59,9 & 51,9 \\ \text { August } & 69,7 & 65,1 \\ \text { September } & 64,1 & 52,3 \\ \text { October } & 68,8 & 54,1 \\ \text { November } & 80,7 & 60,5 \\ \text { December } & 74,5 & 66,5\end{array}$

Fig. 5

another 3 months because of a large change in staffing and many new junior staff members.

2. To issue monthly a simple computerized plan of the sub-sections on evaluation and treatment for each specific department to facilitate improvement of theseareas by the individual physiotherapists. Fig. 6 shov a breakdown of the unit on treatment planning in the sub-section. Care must be given to documenting the treatment plan in all the cases falling to the left of the $M$ value.

3. Practice audit sessions where the auditing committee will audit the same form independently and then discuss the points allocated. It has been shown statistically that some auditors are very strict and others are very lenient. Hopefully practice audit sessions will bring about a more uniform strictness in marking.

\section{CONCLUSION}

There is still much that needs to be learned about the validity and implication of such a documentation audit. It is nevertheless very interesting to see the efficiency of the physiotherapy services numerically evaluated. It is also felt that the whole system serves to remind physiotherapists of the global approach necessary to

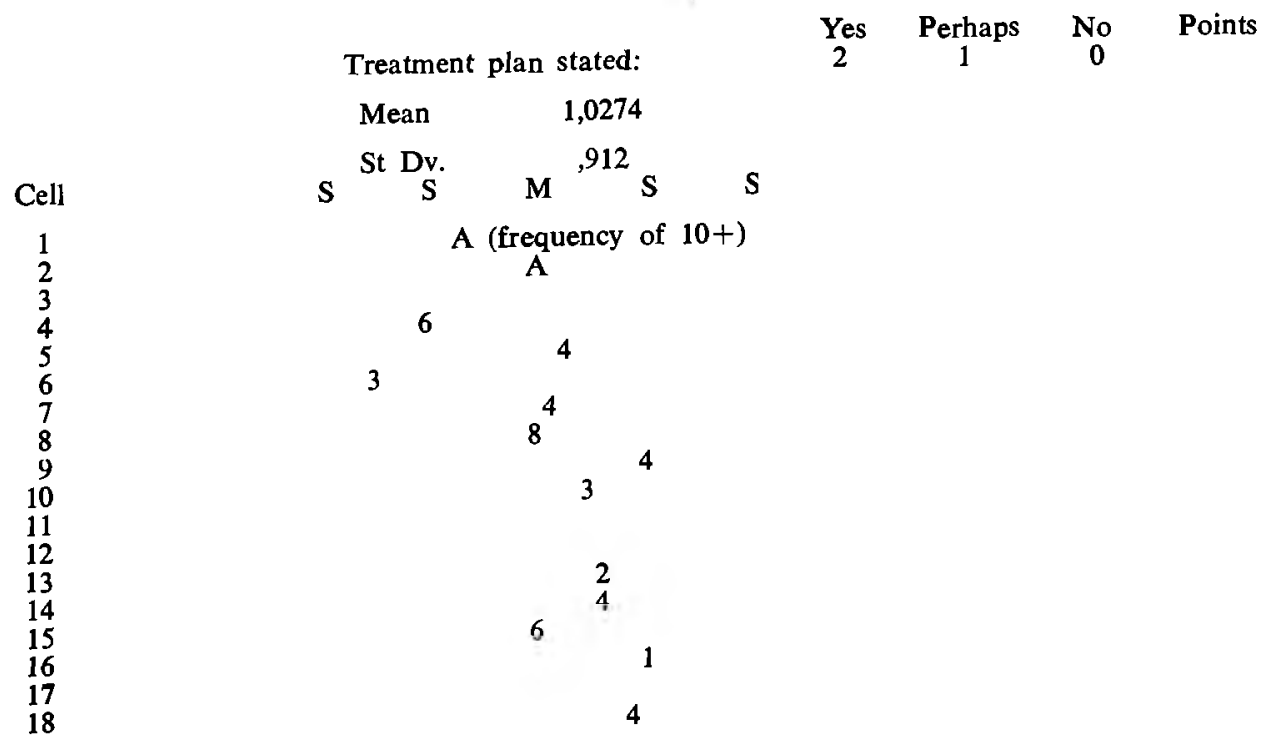

Cells $1-18=$ Various departments e.g. paediatrics, out-patient neurology.

$M=1,0274=$ Mean of total points scored.

Frequency of forms audited $=$ other numerical values. 
patient care which so often tends to fall by the way in this busy world of ours.

\section{References}

Khan, A., Howroyd, H. A. (1976). Physiotherapy care audit and peer review. Physiother. Can. 28, 163.

Weed, L. (1968). Medical records that guide and teach.
New Eng. Jnl. Med, 278, 593.

Weed, L. (1971). Quality control and the medical record. Arch. Int. Med. 127, 101.

\section{Acknowledgements}

Dr. D. J. van Schalkwyk, Department for Biostatistics, South African Medical Research Council.

\title{
PRACTICE MANAGEMENT
}

\author{
PAUL SUlCAS, B.Com., B.A. (Hons.), M.Com., D.Com., C.A.(S.A.), A.C.I.S., A.T.D.P.M.*
}

This article is based on a presentation by the author at the Annual General Meeting of the Private Practitioners Association of the South African Society of Physiotherapy held in Cape Town during February 1979. Various aspects of practice management are dealt with, and suggestions/recommendations made as to possible courses of action which could overcome actual (or potential) areas of concern.

\section{INTRODUCTION}

For many years I have had dealings with physiotherapists. As to professional competence in preventative and remedial treatment there can be no doubt. However, when it comes to general administrative matters there can be no doubt that much can be improved. With this fundamental premise in mind the aspects which follow are intended to provide guidelines in two directions, viz. potential areas of improvement, and/or confirmation that (if you believe it) your practice is well managed and controlled.

\section{ASPECTS OF CONCERN}

The waiting room reflects the image of your pracice. Try to ensure that it is easily accessible and well laid out; furniture to be functionally comfortable and in good condition; the walls, curtains and carpets colourful and matching; potted plants are always eyecatching; periodicals should be of interest to patients and up-to-date; and do be punctual with your appointments!

- 'Administrative' activities are relatively easy to handle provided you do not permit a backlog to build up. Considerable attention should be given to the size, content, durability and layout of the patient record card which, in many instances, also functions as patient's account card. Ensure that all patients are charged, and at the correct rate - double check all additions and subtractions. Rules for alphabetical filing of these cards should be devised in order to facilitate easy location. The handling of payments from patients is always a potential problem area and must be closely monitored. Try to prepare your monthly accounts to patients timeously to reach the patient, if possible, as near to

\footnotetext{
* Associate Professor, Department of Accounting, University of Cape Town.

Received 12 February 1980.
}

\section{OPSOMMING}

Die artikel is gebaseer op 'n voordrag deur die skrywer tydens die Algemene Jaarvergadering van die Privaat Praktisynsassosiasie van die Suid-Afrikaanse Fisioterapie Vereniging gehou te Kaapstad gedurende Februarie 1979. Aspekte van praktyksbestuur word bespreek en voorstellelaanbevelings word gemaak ten opsigte van aksie wat werklike (of potensiele) probleem areas kan bemeester.

month-end as possible (Sulcas, 1976). Delinquent payers can be encouraged to pay by using stickers on accounts, or through personal telephonic contact, or by writing a letter. Remember that if your inflow of cash is bad because of lack of your attention/interest, you could have problems in settling your own outstanding accounts as well as keeping the Receiver of Revenue satisfied!

Security considerations are frequently overlooked. Here specific reference is made to keeping your records locked up in a fire-proof safe during hours when the practice is closed. In addition, equipment can be stolen relatively easily and you should have serial numbers readily available for the police. Finally, check the physical security of your premises for ease of unauthorised entry, or for potential fire hazard circumstances, e.g. your air-conditioning unit.

The method of financing equipment acquisition can be problematic when faced with alternative proposals for purchasing, leasing, or renting. It is suggested that you seek advice from someone who not only understands the implications of these choices, but also fully understands your personal circumstances. Your accountant/auditor would normally be ideal.

If a partnership is operational, or contemplated, ensure that a legally drafted agreement exists setting out the rights and obligations of all parties. Included should be, inter alia, procedures on dissolution or admission of a new partner, and on what happens if one partner dies. Despite the friendship of partners, surprising things can (and do!) take place when problems involving money affairs arise.

With the bulk of your patients being direct referrals from medical practitioners, it should be a standard procedure to report back - this can be done telephonically, but it is recommended that a well written report should be submitted. Not only is a permanent record made for the doctor's files, but the professionalism of your attitude cannot fail to create a good impression. Marketing professionals would call this a sound marketing strategy!

Your personal financial affairs should not be neglected, particularly when looking to the future. Here 